\title{
Bauman, Z., Mazzeo, R. (2019). Edebiyata Övgü. (İngilizceden Çeviren: Akın Emre Pilgir). İstanbul: Ayrıntı Yayınları. 144 sayfa. ISBN: 978-605-314372-7
}

\section{Aziz ŞEKER ${ }^{1}$ (D)}

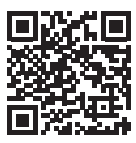

'Dr., Amasya Üniversitesi, Rektörlük, Amasya, Türkiye

ORCID: A.Ş. 0000-0001-5634-0221

Corresponding author:

Aziz ŞEKER,

Amasya Üniversitesi Rektörlüğü/Akbilek Mh Hakimiyet Cd. 4/3, 05100 Amasya, Türkiye

E-mail: shuaziz@gmail.com

Submitted: 04.12.2019

Accepted: 11.02 .2020

Citation: Seker, A. (2020). Edabiyata övgü [Z. Bauman, R. Mazzeo tarafından yayına hazırlanan Edebiyata övgü başlıklı kitabın değerlendirmesi]. Litera, 30(1), 283-288. https://doi.org/10.26650/LITERA2019-0078

\section{Edebiyata Övgü}

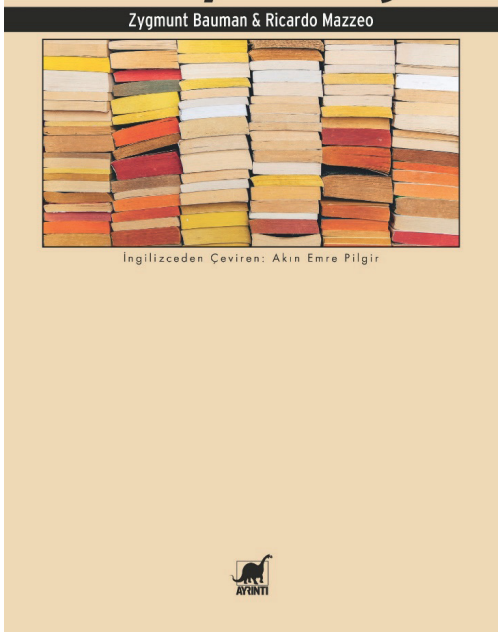

Edebiyata Övgü adından kaynaklı olarak, ilk bakışta edebiyat etrafında klasikleşmiş konuların tartışılığı bir yapıtı akla getirebilir. Ancak kitapta kapsamlı bir biçimde edebiyat sosyologlarının, roman yazarlarının, edebiyat eleştirmenlerinin, sosyal teoriye ilgi duyanların dikkatini çeken olguların ele alındığını söylemek mümkün. Bauman ve Mazzeo tarafından, diğer disiplinlere göre inmal edilmiş olan sosyoloji ve edebiyat arasındaki doğrudan etkileşimin masaya yatırıldığı kitabın kurgusundaki özgünlük, mektuplar aracılığıyla yapılandırılmış on iki farklı söyleşiden oluşmasıdır. 
Edebiyata Övgü ilk neşredildiği 2016 tarihinden sonra Akın Emre Pilgir'in akıcı ve anlaşııı çevirisiyle 2019 yılında Ayrıntı Yayınları́nca basılarak Türk okurla buluşturulmuştur. Kitapla ilgili çözümlemeye geçmeden önce Bauman'ın son bölümde ifade ettiği şu ayrıntının, kitap boyunca insan ve toplum sorunlarıyla birlikte sorgulandığını belirtmek gerekir. Bauman'a göre:

Modern çağda insanın özerk olma, öz yaratıcılığa ve benliğini ortaya koymaya dönük düşleri, insanın yetkinlik sınırlarının ötesine atılmasın diye, tekrar insanların ilgi odağına yerleşme arzusundadırlar. Bu ve diğer varoluşsal meseleleri sorgulamak, bunları tekrar kamuoyunun gündemine taşımak, hem edebiyatın hem de sosyolojinin paylaştığı uğraşlardır. Bu sorunların peşinden gitmek iki yaratıcı çabayı birleştiren unsurdur. Onları birbirlerini tamamlayan unsurlara dönüştürmekte, kalıcı bir etkileşim ile karşılıklı esinlenmelere yol açmaktadır. $(2019$, s. 144)

Kitapta edebiyatın ve sosyolojinin paylaştı̆̆ı uğraşların yanı sıra her iki disiplinin amaç birlikteliklerinin nasıl ele alınacağı irdelenmiştir. Bauman ve Mazzeo'nun, bu söyleşi kitabında sözünü ettikleri gibi, eğer insani koşulların gizemini çözmeye ve önyargılarla, ima edilen veya kendi kendine uydurulan yanlış anlamalarla örülmüş peçeyi kaldırmaya uğraşan bir sosyologsanız, test tüplerinde yaratılıp yetiştirilmiş homunculi'yle ilgili şüpheci ve kibirli "bilgilerle" dolu hakikatten ziyade "gerçek yaşamın peşindeyseniz" Franz Kafka, Robert Musil, Georges Perec, Milan Kundera veya Michel Houllebecq gibi insanlardan feyz almaktan başka pek tercihiniz yoktur. Edebiyat ve sosyoloji birbirini beslemektedir. Ayrıca birbirlerinin bilişsel ufuklarını çizmede işbirliği içinde olup, birbirlerinin gaflarını düzeltmektedirler (2019, s. 8). Kuşkusuz gerek edebiyat gerekse sosyoloji, birbirini bütünlese dahi birbirinden farklı stratejilerden, araçlardan ve yöntemlerden yararlanırken bunların tümünü yerine getirir (en azından yapmaya çalışır ve en fazla çabaladığı kesin bir şekilde söylenebilir). Bunun yanı sıra ne sosyoloji ne de edebiyat, kendi başlarına karşılaştıkları risklerin üzerinden gelebilirler. Ancak güçlerini birleştirmeleri koşuluyla bu riskleri aşabilirler veya bertaraf edebilirler. Dahası onlara birleştikleri anda zafer elde etme şansı veren tam da farklılıklarının kendisidir (2019, s. 9-11).

Her iki yazarın ortaklaşa yazdıkları önsözde, roman ve sosyolojik araştırmalar arasındaki etkileşim de masaya yatırılmıştır. Onlara göre, romanlar ve sosyolojik çalışmalar, aynı meraktan doğar ve bilişsel amaçları ortaktır. Aynı ebeveynlere sahip 
olduklarından, bariz ve su götürmez ailevi benzerlikleri olduğundan, birbirlerinin ilerleyişini hayranlıkla ve arkadaşça bir kıskançlıkla izlerler. Roman yazarları ile sosyolojik metinlerin yazarları son tahlilde aynı toprakları keşfederler (2019, s. 11). Örneğin geçmişte sayısız kere roman yazarları (aynı önsezileri güçlü diğer sanatçılar gibi), çağdaşlarının yüzleştiği ve üstesinden gelmekte zorlandığı zorluklardaki yeni rota değişikliklerini veya yeni eğilimleri ilk fark edip inceleyen kişiler oldular. Yazarlar çoğu sosyoloğun fark etmeyeceği veya umursamayıp marjinal olmaları ya da sözde geri dönüşsüz bir biçimde azınlık statüsüne düşürülmeleri nedeniyle ilgilenmedikleri bir aşamada, yeni kopuşları tespit edip yakalayabilmişlerdir $(2019$, s. 12).

Bauman ve Mazzeo'nun değerlendirmesiyle roman yazarları ve sosyolojik metinleri yazanlar bu dünyayı renkli bakış açılarıyla keşfedebilirler, farklı "veri" türlerinin peşinden koşup bunları üretebilirler. Ortaya koydukları şeyler ise kesinlikle ortak bir kökenin damgasını taşıllar. Birbirlerini beslerler ve yönelimlerinde, keşiflerinde, verdikleri mesajların içeriğinde birbirlerine dayanırlar. Sadece yan yana dururken, birbirlerinin bulgularına kulak verirken ve sürekli diyalog halindeyken, hakikati, tüm hakikati ve beşeri koşulların hakikatini ifşa ederler. Ancak birlikte birey ve toplumun yanı sıra biyografi ve tarihin karmaşık düğümlerini çözme ve açığa çıkarma gibi zorlu bir işin üstesinden gelebilirler (2019, s. 13). Bu açıdan bakıldığında dünyanın hakikatini ifşa eden edebiyat ve sosyolojinin kendi tarihsellikleri bağlamında insan ve toplum sorunlarına asla duyarsız kalmadıklarını söylemek mümkündür. Sonuçta günümüzde de modern zamanların tarihi içinde bir kez daha, roman yazarları kamusal düşüncelerin, tartışmaların ve farklıı̆ın avangardı içinde film-yapımcıları ve görsel sanatçılarla yan yana gelmekte, tüketicilerin oluşturduğu ve çok daha denetimsiz, atomize olmuş ve özelleştirilmiş toplumumuzda, erkek ve kadınların içine düştüğü yeni koşulların anlaşılmasına öncülük etmektedirler $(2019$, s. 12).

Kitabın bölümleri genel hatlarıyla şu şekilde ele alınabilir: Illk bölümde sosyoloji ve edebiyat iki kız kardeş olarak nitelendirilmektedir. Bu temelde girişilecek bir arayışta Mazzeo'nun beklentisi, sosyoloji ve edebiyatın bizi çevreleyen peçelerin kararttığı özgünlüğü yargılayıp açığa çıkarma ve ihtiyaçlarımızın peşinden koşma özgürlüğünü verme imkânını artırmak için birlikte çalışması gerektiği yönündedir (2019, s. 15). Mazzeo, çıkarsamalarda bulunurken, dünyayı, toplumu ve insanları ilgilendiren genel sorunları betimlemekte, bir bakış açısı geliştirmeyi ise Bauman'ın yanıtlamasını istediği sorularla desteklemektedir. Mazzeo'nun iki kız kardeş söylemine, Bauman şu şekilde bir karşılık verir: 
İnsan deneyimi hem yazarların hem de sosyologların tezgâhlarına, hâlihazırda önceden yorumlanmış bir biçimde gelir. Gerek edebiyat gerekse sosyoloji "ikincil hermenötik" çalışmalardır (yani zaten yorumlanmış olan şeyin yeniden yorumlanışıyla uğraşırlar). Bu sebeple her ikisi de, yorumlama perdesinin yırtılmasını sağlayacak saklı dikiş yerlerini aramakla meşgul olmalıdır. Dahası hiçbiri o an yırtmakta oldukları perdelerin arkasına saklanmış, diğer perdeleri açığa çıkarmaktan kaçınamaz. Bizler sizin de söylediğiniz gibi gerçekten de "iki kız kardeşi”iz. Bir adım daha ileriye gidip edebiyatla sosyolojinin öyle sıradan kardeşler olmadığını, siyam ikizleri olduklarını söyleyeceğim. $(2019$, s. 22)

Diyebiliriz ki, yukarıdaki saptamasından hareketle Bauman her iki disiplin için kullanılan iki kız kardeş söylemini, yaşanmış olan ve yaşanabilecek sosyal sorunların edebiyat ve sosyolojinin ilgi alanına girmesinden dolayı bir adım ileri götürerek, siyam ikizlerine benzetmektedir.

Bu diyalog kitabın Edebiyat Yoluyla Kurtuluş kısmında, Bauman dahil olmak üzere birçok sosyal bilimcinin çalışmaları referans alınarak, Mazzeo tarafından, toplumun aşağı tabakalarında yaşayanlar, yani yoksullar için pratik yarar oluşturması anlamında öğretmenlerin yaşamsal rollerine dikkat çekilmekte, bu süreçte edebiyatın işlevinin özgürleştirici ve yeni yollar açıcı olduğu belirtilmektedir. Bauman, Mazzeo'nun bu yorumuna karşılık: “iddeal bir öğretmenin, ümitsiz ve düpedüz düşmanca koşullarda bile o insanca, pek insanca yetkinlikleri teşvik edebilen (ve bunun için uğraşan) biri olduğunu kabul ediyorum" der (2019, s. 39). Ancak Bauman bireysel olarak kurtuluşun edebiyata ya da diğer sanat kollarına yüklenmesinin yararlarının farkında olmakla birlikte, "pratik bir yararı olur mu?" noktasında tarafsız olmasa da eleştirel kalmaktadır.

Çalışmanın içeriğinde Mazzeo, Bauman'ın Sosyoloji Ne Işimize Yarar? isimli (What Use Is Sociology?) kitabına yaptığı göndermelerle günümüz toplumuna ilişkin saptamalara ağırlıklı yer ayırarak, farklı bölümler arasındaki tematik bütünlüğü sürdürücü bir yol izlemektedir. Sarkaç ve Calvino'nun Boş Merkezi isimli bölümde, Batı'da bekar annelerinin sayısının artması, insanların sosyalleşme becerilerini ortadan kaldıran internet çağının bireylere yansımaları konu ediniyor. Baba Sorunu söyleşisinde, baba figürünün değişmesine rağmen Batı toplumu dahil olmak üzere, 
hala ataerkil toplumların baskın olduğu üzerinde duruluyor. Edebiyat ve Hükümdarsız Dönem'de, Mazzeo'nun, eski ve henüz kurulamamış yeni yaşam tarzı arasındaki hissedilen duyguyu ifade eden edebiyatın, neler anlatabileceği noktasındaki arayışına karşılık, edebiyatın aynı sosyolojide olduğu gibi, insanların aradığı, benimsediği veya karşısına çıkan hakikatin yolları konusunda hakikatin keşfedilmesine odaklandığının altı çiziliyor (2019, s. 59-65).

Blog ve Aracıların Kayboluşu'nda, insanın benlik arayışı sürecinde, blog ve Twitter'ın, edebiyata ilgiyi düşürürken bazı hasarlarının olacağı varsayılıyor. Bunun devamı niteliğindeki Hepimiz Otistikleşiyor muyuz? söyleşisinde ise sosyal ağ sitelerinin bu gidişatı hızlandırdığına ironik bir gönderme yapılmaktadır. 21. Yüzyılın Metaforları'nda, Marcel Proust'un, toplumsal maskelerin ötesine geçip insanları tanımlayan sözcükleri ararken metaforlara başvurmasına dikkat çekilmiştir. Bauman'ın, 21. yüzyıl toplumunu anlamak adına geliştirdiği "akışkan modernlik" tabiri ise yüzyılın metaforları arasında örneklenirken Tani'nin ekran, alzheimer ve zombi metaforları üzerinde de duruluyor. Kitabın Twitter Edebiyatını Göze Almak kısmında, insanların yalıtılmışlıkla ve bireyselleşme ile lanetlenmesinde elektronik teknolojinin etkisi gözler önüne serilmiştir. Kuru ve Nemli'de, teknolojinin beslediği süreçlerin, edebiyatı hükümsüz kılan tedrici bir sürecin yaşanmasındaki rolü tartışılmaktadır. Bununla baş etme noktasında, edebiyatın sarsılmaz ve inatçı özelliğinin altı çizilmektedir. Mazzeo, burada, Twitter edebiyatının yok edemeyeceği kitaplara; Michel Houellebecq'in Bir Adanın Olasılığı, Albert Camus'un Veba, Saramago'nun Körlük, Jonathan Littell'nin Iyilikseverler, Alberto Garlini'nin Nefret Kanunu çalışmalarını örnek olarak vererek, bu tür yapıtların "hem sosyologlar hem de kitleler içinde düşünceyi beslemeye devam edeceğine" (2019, s. 116) vurgu yapıyor. Mazzeo'nun aktarımlarına karşııı, Bauman ise düşüncelerini şu şekilde ifade etmektedir: "Edebiyat ve sosyal bilimler arasındaki işbirliği, insanların varoluşunu ve birlikte sürdürdükleri yaşamın sorgulandığı diğer birçok alanda olduğu gibi, burada da içten ve samimi olduğu kadar etkili olabilmektedir" (2019, s. 119). "Teklik" Içinde Kısıntıya Gitme söyleşisinde, başkalarını anlamakta edebiyatın taşıdığı önem merkeze alınarak çözümlemeler yapılmaktadır. Kitabın son söyleşisiyse Eğitim, Edebiyat, Sosyoloji adını taşımaktadır. Bu söyleşi aynı zamanda kitaba ilişkin çeşitli tartışmaların gözden geçirildiği ve özetlendiği bölümü oluşturmaktadır. Burada, sosyoloji ve edebiyat arasındaki yakın bağ üzerinde durulmaktadır. Mazzeo, sosyoloji ve edebiyatın ortak alınyazısını, "hayal gücü, analiz, analiz edilen halay gücü" olarak somutlaştırırken, sanat ve yaşam arasındaki diyalektiğe Bauman'ın yaklaşımı şöyle olur: 
Sosyologlar ve roman yazarları olarak, insanların yaşadıkları koşullar içinde muazzam gücünü görünmezliklerinden alan en gizli ve içsel yaşam kaynaklarını görmelerine, yaşamlarını sürdürme yollarına anlam, amaç ve değer aşılamaya çabalarken, yaşamın getirdiği belirsiz tuzaklardan ve pusulardan uzak durmalarına yardımcı olmakla yükümlü bizler, sözcüklerden başka hiçbir araca sahip değildir. (2019, s. 137)

Sözcüklerin öneminin yanında, yine Bauman'ın ifadesiyle "çağımıza ait çıkmaz, dönüp dolaşıp sorgulanmanın inmal edilmesi, reddedilmesi veya öğrenilmiş sorgulayamama halidir" (2019, s. 139).

Son tahlilde Edebiyata Övgü (In Praise of Literature) kitabı, sosyoloji ile edebiyat arasındaki ilişkiyi çözümlerken, bir edebiyatçı ile sosyoloğun dünya sorunları karşısındaki bakış açısı zenginliğini yansıtmaktadır. Hiç şüphesiz bir edebiyat sosyolojisi niteliğindeki bu çalışma, geçmişin ve günümüz dünyasının sosyal gerçekliğini kavramak adına edebiyatın çeşitli alanlarına ve sosyal teoriye ilgili duyanlar için yeni düşünsel pencerelerin açılmasına katkı sağlayacaktır.

\section{Kaynakça}

Bauman, Z. ve Riccardo, M. (2019). Edebiyata övgü. (A. Emre Pilgir, Çev.). İstanbul: Ayrıntı Yayınları. 